\title{
Gülten Dayığlu Çocuk ve Gençlik Edebiyatı Ödülleri’nde Yılın Romanı Ödülünü Kazanan Eserlerin Duyarlık Eğitimi Açısından İncelenmesi
}

Enes ÇİNPOLAT*

\author{
$\ddot{O}_{z}$
}

Bu araştırmanın amacı Gülten Dayıŏlu Çocuk ve Gençlik Edebiyatı Ödülleri'nde seçici kurul tarafından yılın çocuk romanı olarak seçilen kitapları duyarlık eğitimi açısından incelemektir. Nitel araştırma yaklaşımıyla yürütülen çalışmada temel nitel araştırma deseni kullanılmıştır. Araştırmada 2007 yılından itibaren verilmeye başlanan bu ödüllerde yılın çocuk romanı ödülünü kazanan altı kitap incelenmiştir. Araştırmanın verileri doküman inceleme yöntemi ile toplanmıştır. Verilerin analizinde ise içerik analizi kullanılmıştır. Araştırmadan elde edilen bulgulara göre incelenen kitaplarda genel olarak insana, insan mutluluğuna duyarlık, aşka-sevgiye duyarlık, hayvanlara duyarlık, aile bireylerine duyarlık, emeğe ve çalışkanlığa duyarlık, doğaya-çevreye duyarlık, sanat ve estetik olana duyarlık, okuma kültürüne duyarlık, dostluk ve arkadaşlığa duyarlık alanlarına ilişkin konular tespit edilmiş̧ir. Araştırma sonuçlarına göre incelenen kitapların çocukları çeşitli konularda duyarlı kılabilecek içerikler barındırdıkları saptanmıştır.

Anahtar kelimeler: Türkçe eğitimi, çocuk edebiyatı, roman, duyarlık.

\section{Examination of the Works that Won the Novel of the Year Award at the Gülten Dayığlu Children's and Youth Literature Awards in terms of Sensitivity Education}

\begin{abstract}
The purpose of this research is to examine the books selected as the children's novel of the year by the selection committee in Gülten Dayığlu Children and Youth Literature Awards in terms of sensibility education. In this study conducted with a qualitative research approach, basic qualitative research design was used. In the research, six books that won the children's novel award of the year in these awards, which have been awarded since 2007, were examined. The data of the research were collected by document analysis method. Content analysis was used in the analysis of the data. According to the findings obtained from the research, the books examined are mostly related to sensitivity to happiness, sensitivity to love, sensitivity to animals, sensitivity to family members, sensitivity to labor and diligence, sensitivity to nature-environment, sensitivity to art and aesthetics, sensitivity to reading culture, sensitivity to friendship. According to the results of the research, it was determined that the examined books contain contents that would make children sensitive on various subjects.
\end{abstract}

Keywords: Turkish language education, children's literature, novel, sensitivity.

Geliş/Received: 15.07 .2021

Kabul/Accepted: 30.12 .2021

- Bu çalışma, insanlardan veri ve örnek toplamayı gerektiren, anket, inceleme, alan çalışması ve deney içeren araştırmalar kapsamında yer almaması nedeniyle etik kurul onay belgesi gerektirmemektedir.

\section{Giriş}

Edebiyat kavramı Kavcar (1999: 4) tarafından “çağlar boyunca insanoğlunun duyduğu, düşündüğü ve yaptığı her şeyi en zengin ve en etkili biçimde ortaya koyan bir sanat" alanı olarak tanımlanmaktadır. Güzel sanatlar içerisinde yer alan edebiyat, hayatın yansımasının insana dilin anlatım gücüyle aktarılması ile gerçekleşmektedir. Böylelikle bu yansımalar tüm bireylere metinler ile aktarılmıştır. Ancak on altıncı yüzyılda batıda yaşanan gelişmeler neticesinde çocuk fikri üzerine eğilme ile çocuk edebiyatı gündeme gelmiştir (Şirin, 2016). Böylelikle çocuklara sunulan eserlerin yetişkinler için yazılan eserlerden farklılaşma süreci başlamıştır. Ülkemizde ise çocuk edebiyatının ilk adımları Tanzimat döneminde atılmaya başlanmıştır (Karagöz, 2018).

\footnotetext{
${ }^{*}$ Arş. Gör., Ordu Üniversitesi, Eğitim Fakültesi, Türkçe ve Sosyal Bilimler Eğitimi Bölümü, enescinpolat@ gmail.com, 0002-3411-4300

(Makale Türü: Araştırma Makalesi)
} 


\section{Gülten Dayığlu Çocuk ve Gençlik Edebiyatı Ödülleri’nde Yılın Romanı Ödülünü Kazanan Eserlerin Duyarlık Eğitimi Açısından İncelenmesi}

Çocuk edebiyatı, Oğuzkan (2013: 3) tarafından "usta yazarlar tarafından özellikle çocuklar için yazılmış olan ve üstün sanat nitelikleri taşıyan eserlere verilen genel ad"; Sever (2017: 17) tarafından ise "erken çocukluk döneminden başlayıp ergenlik dönemini de kapsayan bir yaşam evresinde, çocukların dil gelişimi ve anlama düzeylerine uygun olarak duygu ve düşünce dünyalarını sanatsal niteliği olan dilsel ve görsel iletilerle zenginleştiren, beğeni düzeylerini yükselten ürünlerin genel adı" şeklinde tanımlanmaktadır. Dilidüzgün (1996) de çocuk edebiyatının yetişkin edebiyatına geçişte "ara basamak" oluşturduğunu belirtmektedir. Buna göre çocuk edebiyatının çocuğu yetişkinliğe hazırlayan destekleyici özelliklerinin bulunmas1 gerekir.

$\mathrm{Bu}$ bağlamda çocuk edebiyatı eserlerinin işlevlerinin bireyin gelişimi üzerindeki etkisinin oldukça büyük olduğu söylenebilir. Çocuk edebiyatı eserlerinin temel işlevleri; okuma alışkanlığının ve sevgisinin kazanılması, edebiyat duyarlılığının gelişmesi, bireyin kendi kimliğinin oluşmasına katkı sağlaması, gelişim alanlarını (dil, bilişsel, sosyal, psikomotor) desteklemesi, duygu, düşünce ve hayal dünyasını geliştirmesi olarak sıralanabilir (Dilidüzgün, 1996; Sever, 2017; Şirin, 2016; Tekşan, 2016). Karagül (2019) ise Felski'nin yaklaşımı doğrultusunda çocuk edebiyatının temel işlevlerini incelediği çalışmasında çocuk edebiyatının işlevlerinin önemine değinerek dört temel işlevi aktarmaktadır. Bunlardan birincisi olan tanıma işlevi insanı ve yaşamı tanımaya olanak verir. İkincisi olan büyüleme işlevi çocukların hayal dünyalarını ve yaratıcılık becerilerini geliştirir. Bilgilendirme işlevi günlük deneyimleri ve toplumsal yaşam işleyişini algılayabilmeye fayda sağlar. Şaşırtma işlevinin ise çocukların gerçeği aramasını ve sorgulamasını bilen bireyler olmaları yönünde çocuklarda önemli farkındalıklar oluşturan bir işlev olduğu belirtilmektedir (Karagül, 2019). Buradan görüldüğü üzere çocuk edebiyatı ürünleri çocukları hayata hazırlayan önemli işlevler üstlenmektedir. Kişiyi hayatındaki olaylara, kişilere karşı duyarlı bireyler olarak hazırlamanın da bu işlevler ile bağlantılı olduğu söylenebilir. Aslan (2013) da nitelikli çocuk edebiyatı eserlerinin önemli bir işlevinin de duyuları devindirerek çocukları duyarlı kılmak olduğunu belirmektedir.

Duyarlık kavramı, çalışma konusuyla ilgili olarak bireyin "kendi yaşamı, kendi dünyası dışında olup bitenlerle ilgilenme; bunları umursama, sezip değerlendirebilme ve bu dış uyaranlara karşı bilinçli/uyanık olma, tepkide bulunma; olanlardan, insanların yaşadıkları olay ve duygulardan etkilenme ve olanları görmezden/bilmezden gelmeme; başkalarının duyum ve duygularını kendilerini onların yerine koyma yoluyla anlama, duyumsama hatta yaşama yeteneği” şeklinde tanımlanmaktadır (Aslan, 2013: 29). Görüldüğü üzere duyarlık kavramı kişilerin çevrelerinde olanlara ve insanlara karşı etkileşime açık olma, durumları algılama yetileri ile ilgilidir. Çağımızdaki ben merkezli tutumun artışı ile duyarlı olma konusu önem kazanmıştır. Duyarlı olma yetisi bireyin doğuştan getirdiği bir özellik olmadığı için eğitim ile kazandırılır (Karakuş Aktan, 2019). Bu sebeple duyarlı olma durumunun kazandırılması bir süreç gerektirmektedir. Duyarlığın geliştirilmesine yönelik yapılabilecek çalışmalarda en önemli uyaranlardan biri 
olan çocuk edebiyatı eserleri ile ilk çocukluk evresinden başlanarak çocuğun duyarlık algısı desteklenebilir (Karakuş Tayşi, 2019). Belirli uyaranlar ile çocuğa duyarlık yeteneğinin kazandırılmasında duyarlık eğitimi işe koşulmaktadır. Duyarlık eğitimi, "insanı yaşadığı toplum ve dünyadaki olaylara, olgulara, sorun ve çıkmazlara, yaşama, insana ve doğaya karşı edebiyat yapıtlarının sezdirimleriyle duyarlı kılmaya yönelik eğitim" olarak açıklanmaktadır (Aslan, 2019: 3). "Duyarlık eğitiminde amaç, insanc1l değerleri, çocuğun yaşına ve gelişimine uygun bir kurgu aracılığıyla çocuğa sezdirmek ve çocukta üzerinde durulan konu ile ilgili duyarlık oluşturmaktır.” (Alemdar ve Süngü, 2017: 304). Bunu gerçekleştirebilmesi için çocuk edebiyatı eserlerinin bir duygu veya bir sorun karşısında çocukların duyularını harekete geçirerek duyarlık oluşturmalıdır (Aslan, 2013). Yazar, iletileri olaylar ve kahramanlar ile çocuğa sezdirmelidir (Alemdar ve Süngü, 2017). Yani çocuk kitapları çocuklara neler yapması ya da yapmaması gerektiğini doğrudan söylemeden bunun için düşündürmelidir. Bu şekilde çocuklara davranış ve eylemlerinin başkaları üzerinde yaratacağı duygusal sonuçlar, çocukların duyarlıkları işletilerek buldurulmalıdır (Sever, 2017: 22).

Yukarıda belirtilen özelliklere sahip nitelikli çocuk edebiyatı eserleri ve diğer uyaranlar ile duyarlık eğitimi görerek duyarlık yeteneği kazanan çocuklar başka insanların acılarını ve sorunlarını duyumsayabilir, haksızlığa uğramış insanların yanlarında yer alır ve yapılanlara tepki gösterir, her zaman insan hak ve özgürlüklerinin savunucusu olur, etik ve ahlaklı olandan yana karar verir, özerk olabilir, önyargı ve kalıp yargılardan arınarak farklılıklarla bir arada yaşayabilmeyi kavrar, doğayı korur (Aslan, 2019: 72).

İlgili alanyazın incelemesi yapıldığında, Aslan'ın (2016) Oğuz Tansel’in masallarını; Alemdar ve Süngü'nün (2017) Nazım Hikmet'in Sevdalı Bulut adlı kitabını; Karagöz ve Çinpolat'ın (2017) Füsun Çetinel 'in çocuk romanlarını; Karakuş Tayşi'nin (2019) Sevim Ak’ın çocuk öykülerini; Karagöz, Sezer ve Sarman'ın (2019) Necati Güngör'ün çocuk öykülerini duyarlık eğitimi açısından incelediği görülmektedir. Bunların yanı sıra Arslan (2013; 2019) ve Karakuş Aktan'ın (2019) da duyarlık eğitiminde çocuk edebiyatının yerini tartıştığı kuramsal çalışmaları bulunmaktadır. Bu çalışma incelemeye aldığı eserler yapılan çalışmalardan farklı olması ve bu eserlerin bir seçici kurul tarafından ödül kazanması sebepleri ile diğer araştırmalardan farklılık göstermektedir. Böylelikle bu eserlerin hangi alanlarda duyarlıklar içerdiğinin tespit edilmesi alana katkı sağlayacaktır.

Edebiyat, didaktik değil duyuşsal ve sanatsal bir süreç olduğu için bireyi duyarlı kılmada etkili bir araçtır (Karakuş Tayşi, 2019). Karagöz’ün (2017) çalışmasında da çocuk edebiyatı eserlerinin yaşama karşı duyarlıklar geliştirmede işlevsel bir rol üstlendiği dile getirilmiştir. Böylelikle kişiyi çeşitli konularda duyarlı k1lma gücüne sahip nitelikli edebi eserlerin çocuklarla buluşturulması önemli ve gerekir (Aslan, 2013). Bu yüzden çocuk edebiyatı eserlerinin duyarlık eğitimi açısından incelenmesi anne-baba ve öğretmenlerin çocukları nitelikli kitaplarla buluşturabilmesi açısından bir değerlendirme içerdiği için önemlidir. Bu araştırmanın amacı Gülten Dayığlu Vakfı tarafından yıllık düzenlenen Gülten Dayıŏlu Çocuk ve Gençlik Edebiyatı Ödülleri'nde akademisyen ve yazarlardan oluşan seçici kurul tarafından yılın çocuk romanı olarak seçilen kitapları duyarlık eğitimi açısından incelemektir. 


\section{Gülten Dayığlu Çocuk ve Gençlik Edebiyatı Ödülleri’nde Yılın Romanı Ödülünü Kazanan Eserlerin Duyarlık Eğitimi Açısından İncelenmesi}

\section{Yöntem}

\section{Model}

$\mathrm{Bu}$ araştırma nitel araştırma yaklaşımına uygun hazırlanmıştır. Araştırmada incelemeye alınan kitapları belirli bir çerçeve içerisinde değerlendirip, anlamlandırıp, yorumlama yoluna gidileceği sebebiyle temel nitel araştırma deseninden yararlanılmıştır. Temel nitel araştırmada anlamların irdelenmesi ve yorumlanması amaçlanmaktadır (Merriam, 2013).

\section{Verilerin Toplanması ve Analizi}

Araştırmada verilerin toplanmasının kitapların duyarlık eğitimi açısından incelenmesi şeklinde gerçekleştirileceği için doküman incelemesi yöntemi kullanılmıştır. Doküman inceleme yöntemi, araştırılması hedeflenen olgu veya olgular hakkında bilgi içeren yazılı materyallerin analizini kapsamaktadır (Yıldırım ve Şimşek, 2011).

Verilerin analizinde ise içerik analizi kullanılmıştır. İçerik analizinde temel amaç, birbirine benzeyen verileri belirli kavramlar ve temalar çerçevesinde bir araya getirmek ve bunları okuyucunun anlayacağı biçimde düzenleyerek yorumlama işlemidir (Yıldırım ve Şimşek, 2011). Araştırmada içerik analizi çeşitlerinden ise kategorisel analiz kullanılmıştır. Kategorisel analizde önce veriler kodlanmıştır. Kodlar, kelime gruplarını sınıflandırmak ya da gruplandırmak için kullanılan semboller; araştırma sorularıyla ilgili olan kavramlardır (Robson, 2001). Verilerin toplanmasına başlanmadan önce kitaplar araştırmacı tarafından bir defa okunmuştur. Daha sonra kitaplar, önceden belirlenen duyarlık kategorilerine göre kodlama yapılmak amacıyla okunmuştur. Kodlama amaçlı yapılan okumanın ardından elde edilen veriler kategorilere göre ayrılarak görsellerde frekans olarak verilmiştir. Görselleştirme amacıyla MAXQDA 12 nitel veri analizi programı kullanılmıştır.

Araştırmada Aslan'ın (2013) ve Karagöz'ün (2009) çalışmalarının dikkate alındığı, Karagöz, Sezer ve Sarman'ın (2019) çalışmasında kullanılan duyarlık kategorileri kullanılmıştır. Çalışmada belirlenen kategoriler aşağıdaki Tablo 1'de belirtilmiştir.

Tablo 1: Duyarlık kategorileri

\begin{tabular}{|c|c|c|c|}
\hline \multicolumn{4}{|c|}{ Kategoriler } \\
\hline 1. Dilsel duyarlık & 8. İyilik yapmaya duyarlık & 15. Dürüstlüğe duyarlık & $\begin{array}{l}\text { 22. Zararlı alışkanlıklara } \\
\text { karşı duyarlık }\end{array}$ \\
\hline $\begin{array}{l}\text { 2. İnsana, insan } \\
\text { mutluluğuna duyarlık }\end{array}$ & 9. Paylaşmaya duyarlık & $\begin{array}{l}\text { 16. Bilime ve bilimsel } \\
\text { düşünceye duyarlık }\end{array}$ & $\begin{array}{l}\text { 23. Umuda-umutlu } \\
\text { olmaya duyarlık }\end{array}$ \\
\hline 3. Kadına duyarlık & $\begin{array}{l}\text { 10. Toplumsal huzura } \\
\text { duyarlık }\end{array}$ & $\begin{array}{l}\text { 17. Doğaya-çevreye } \\
\text { duyarlık }\end{array}$ & $\begin{array}{l}\text { 24. Dostluk ve } \\
\text { arkadaşlığa duyarlık }\end{array}$ \\
\hline 4. Aşka-sevgiye duyarlık & $\begin{array}{l}\text { 11. Yardımlaşmaya } \\
\text { duyarlık }\end{array}$ & $\begin{array}{l}\text { 18. Geleneksel olana } \\
\text { duyarlık }\end{array}$ & $\begin{array}{l}\text { 25. Sorumlu olmaya } \\
\text { duyarlık }\end{array}$ \\
\hline
\end{tabular}




\begin{tabular}{lll}
\hline 5. Hayvanlara duyarlık & $\begin{array}{l}\text { 12. Emeğe ve çalışkanlığa } \\
\text { duyarlık }\end{array}$ & $\begin{array}{l}\text { 19. Sanat ve estetik olana } \\
\text { duyarlık }\end{array}$ \\
6. Aile bireylerine & 13. Yoksul insanlara & 20. Okuma kültürüne \\
duyarlık & duyarlık & duyarlık \\
7. Barışa duyarlık & $\begin{array}{l}\text { 14. Hakka, hukuka, adalete } \\
\text { duyarlık }\end{array}$ & 21. Temizliğe duyarlık \\
\hline
\end{tabular}

\section{İncelenen Dokümanlar}

Araştırma kapsamında Gülten Dayığlu Çocuk ve Gençlik Edebiyatı Ödülleri’nde çocuk romanı kategorisinde birincilik kazanan romanlar incelenmiştir. 2007 yılından itibaren verilmeye başlanan bu ödüllerde toplamda altı kez yılın çocuk romanı ödülü verilmiştir (bkz. http://www.gultendayioglu.com/gulten-dayioglu-vakfi). Araştırmada da bu altı kitap incelemeye alınmıştır. Araştırmada incelemeye alınan kitaplar, akademisyen ve yazarlardan oluşan seçici kurul tarafından yılın çocuk romanı olarak seçilmiştir. Kitapların bu şekilde bir değerlendirme sürecinden geçerek kendilerini kanıtlamış olması bu kitapların inceleme için tercih edilmesinde etken olmuştur. Bu kitaplara ilişkin ayrıntılı bilgi aşağıda Tablo 2'de sunulmuştur.

Tablo 2: Gülten Dayığlu Çocuk ve Gençlik Edebiyatı Ödülleri’nde çocuk romanı kategorisinde birincilik kazanan romanlar

\begin{tabular}{|c|c|c|c|c|c|c|}
\hline \# & Kitap Ad 1 & Yazar Adı & $\begin{array}{l}\text { Ödül } \\
\text { Y1l1 }\end{array}$ & $\begin{array}{l}\text { Basim } \\
\text { Y1l1 }\end{array}$ & Yayınevi & $\begin{array}{l}\text { Sayfa } \\
\text { Sayis1 }\end{array}$ \\
\hline 1 & Canı Sıkılan Çocuk & $\begin{array}{l}\text { Dursun Ege } \\
\text { Göçmen }\end{array}$ & 2007 & 2008 & Altın Kitaplar & 96 \\
\hline 2 & Masal Kenti Çocukları & Zehra Topunç & 2007 & 2008 & Altın Kitaplar & 144 \\
\hline 3 & Hayalet Köy & Hüsnan Şeker & 2011 & 2012 & Altın Kitaplar & 128 \\
\hline 4 & Komşumuz Çok Acayip & Miyase Sertbarut & 2013 & 2014 & Altın Kitaplar & 152 \\
\hline 5 & $\begin{array}{l}\text { Düşlerin Peşindeki } \\
\text { Çocuk }\end{array}$ & $\begin{array}{l}\text { Koray Avc1 } \\
\text { Çakman }\end{array}$ & 2015 & 2016 & Altın Kitaplar & 144 \\
\hline 6 & $\begin{array}{l}\text { Yaban Ördeği Ailesinin } \\
\text { Göç Yolculuğu }\end{array}$ & Ömür Kurt & 2017 & 2018 & Altın Kitaplar & 96 \\
\hline
\end{tabular}

\section{Geçerlik ve Güvenirlik}

Çalışma belgelerini oluşturan kitaplar duyarlık kategorilerine göre kodlanmıştır. Daha sonra güvenilirliği sağlamak için araştırmacı tarafından kodlamalar sekiz hafta sonra ikinci defa gerçekleştirilmiş ve kendi arasındaki tutarlılığa bakılmıştır. Bunun için Miles ve Huberman'ın (1994) şu formülü kullanılmıştır: Güvenilirlik Katsayısı = Üzerinde görüş birliği sağlanan konu ya da terim sayısı $\div$ (Üzerinde görüş birliği bulunmayan konu ya da terim sayısı + Üzerinde görüş birliği sağlanan konu ya da terim sayıs1) $\times$ 100. İçsel tutarlılığı veren bu kodlama denetiminde elde edilen sonucun en az \%70 düzeyinde olması beklenmektedir (Miles \& Huberman, 1994). Yapılan tekrar kodlamanın ardından güvenilirlik katsayısının $.91(\% 91)$ olduğu tespit edilmiştir. Ayrıca geçerliği artırma amacıyla kategorilere ait doğrudan alıntılara da yer verilmiştir.

\section{Bulgular}

$\mathrm{Bu}$ bölümde, araştırma kapsamında incelenen kitaplardan elde edilen bulgular tablo ve görseller halinde sunularak doğrudan alıntılarla desteklenmiştir. 
Tablo 3: İncelenen kitaplarda tespit edilen duyarlık kategorilerinin dağılımı

\begin{tabular}{|c|c|c|c|c|c|c|c|c|c|c|c|c|c|c|}
\hline \multirow[t]{2}{*}{ Duyarlık Kategorisi } & \multicolumn{2}{|c|}{ 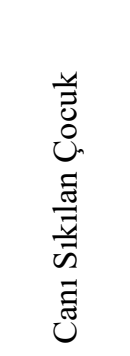 } & \multicolumn{2}{|c|}{ 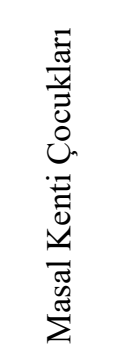 } & \multicolumn{2}{|c|}{ 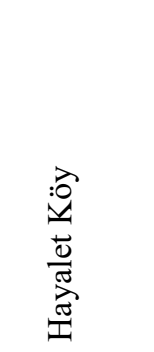 } & \multicolumn{2}{|c|}{ 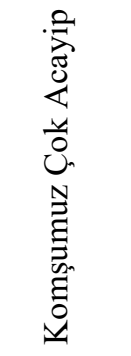 } & \multicolumn{2}{|c|}{ 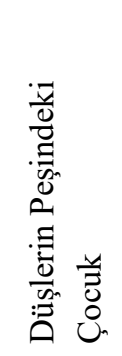 } & \multicolumn{2}{|c|}{ 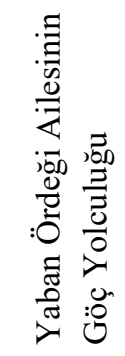 } & \multicolumn{2}{|c|}{$\frac{\Xi}{\tilde{\Xi}}$} \\
\hline & $\mathrm{f}$ & $\%$ & $\mathrm{f}$ & $\%$ & $\mathrm{f}$ & $\%$ & $\mathrm{f}$ & $\%$ & $\mathrm{f}$ & $\%$ & $f$ & $\%$ & $\mathrm{f}$ & $\%$ \\
\hline 1. Dilsel duyarlık & - & - & - & - & 3 & 3 & 2 & 3 & - & - & - & - & 5 & 1 \\
\hline $\begin{array}{l}\text { 2. İnsana, insan } \\
\text { mutluluğuna duyarlık }\end{array}$ & 8 & 13 & 15 & 17 & 20 & 18 & 9 & 12 & 11 & 12 & 12 & 18 & 75 & 15 \\
\hline 3. Kadına duyarlık & - & - & 2 & 2 & 1 & 1 & 1 & 1 & - & - & - & - & 4 & 0.8 \\
\hline 4. Aşka-sevgiye duyarlık & - & - & - & - & 7 & 6 & 14 & 18 & 4 & 4 & 4 & 6 & 29 & 6 \\
\hline 5. Hayvanlara duyarlık & 5 & 8 & 2 & 2 & 2 & 2 & 14 & 18 & 6 & 7 & 13 & 19 & 42 & 8 \\
\hline $\begin{array}{l}\text { 6. Aile bireylerine } \\
\text { duyarlık }\end{array}$ & 5 & 8 & 10 & 11 & 12 & 11 & 5 & 6 & 16 & 18 & 3 & 4 & 51 & 10 \\
\hline 7. Barışa duyarlık & - & - & 2 & 2 & - & - & - & - & - & - & - & - & 2 & 0.4 \\
\hline $\begin{array}{l}\text { 8. İyilik yapmaya } \\
\text { duyarlık }\end{array}$ & - & - & 1 & 1 & 3 & 3 & - & - & 8 & 9 & 1 & 1 & 13 & 3 \\
\hline 9. Paylaşmaya duyarlık & 1 & 2 & - & - & 2 & 2 & 2 & 3 & - & - & 1 & 1 & 6 & 1 \\
\hline $\begin{array}{l}\text { 10. Toplumsal huzura } \\
\text { duyarlık }\end{array}$ & 2 & 3 & 4 & 4 & - & - & 3 & 4 & - & - & 2 & 3 & 11 & 2 \\
\hline $\begin{array}{l}\text { 11. Yardımlaşmaya } \\
\text { duyarlık }\end{array}$ & 4 & 6 & 5 & 6 & 5 & 4 & 3 & 4 & 4 & 4 & 2 & 3 & 23 & 5 \\
\hline $\begin{array}{l}\text { 12. Emeğe ve } \\
\text { çalışkanlığa duyarlık }\end{array}$ & 6 & 10 & 10 & 11 & 5 & 4 & 2 & 3 & 8 & 9 & - & - & 31 & 6 \\
\hline $\begin{array}{l}\text { 13. Yoksul insanlara } \\
\text { duyarlık }\end{array}$ & - & - & 1 & 1 & 5 & 4 & - & - & 1 & 1 & 1 & 1 & 8 & 2 \\
\hline $\begin{array}{l}\text { 14. Hakka, hukuka, } \\
\text { adalete duyarlık }\end{array}$ & 1 & 2 & 1 & 1 & - & - & 1 & 1 & - & - & - & - & 3 & 0.6 \\
\hline 15. Dürüstlüğe duyarlık & 1 & 2 & - & - & 1 & 1 & 1 & 1 & - & - & - & - & 3 & 0.6 \\
\hline $\begin{array}{l}\text { 16. Bilime ve bilimsel } \\
\text { düşünceye duyarlık }\end{array}$ & 1 & 2 & 6 & 6 & 3 & 3 & - & - & - & - & - & - & 10 & 2 \\
\hline $\begin{array}{l}\text { 17. Doğaya-çevreye } \\
\text { duyarlık }\end{array}$ & 5 & 8 & 3 & 3 & 10 & 9 & 5 & 6 & 8 & 9 & 24 & 35 & 55 & 11 \\
\hline $\begin{array}{l}\text { 18. Geleneksel olana } \\
\text { duyarlik }\end{array}$ & 1 & 2 & - & - & 6 & 5 & 2 & 3 & 7 & 8 & 1 & 1 & 17 & 3 \\
\hline $\begin{array}{l}\text { 19. Sanat ve estetik } \\
\text { olana duyarlik }\end{array}$ & - & - & 12 & 13 & - & - & 9 & 12 & 8 & 9 & - & - & 29 & 6 \\
\hline $\begin{array}{l}\text { 20. Okuma kültürüne } \\
\text { duyarlık }\end{array}$ & 8 & 13 & 3 & 3 & 9 & 8 & - & - & - & - & - & - & 20 & 4 \\
\hline 21. Temizliğe duyarlık & 2 & 3 & - & - & 3 & 3 & 1 & 1 & - & - & - & - & 6 & 1 \\
\hline $\begin{array}{l}\text { 22. Zararlı alışkanlıklara } \\
\text { karşı duyarlık }\end{array}$ & 1 & 2 & - & - & - & - & - & - & - & - & - & - & 1 & 0.2 \\
\hline
\end{tabular}


Karadeniz Sosyal Bilimler Dergisi, Sonbahar 2021, Y. 13, S. 25, s.854-872

\begin{tabular}{lllllllllllllll}
\hline $\begin{array}{l}\text { 23. Umuda-umutlu } \\
\text { olmaya duyarlık }\end{array}$ & - & - & 2 & 2 & 2 & 2 & - & - & 3 & 3 & 3 & 4 & 10 & 2 \\
\hline $\begin{array}{l}\text { 24. Dostluk ve } \\
\text { arkadaşlığa duyarlık }\end{array}$ & 6 & 10 & 8 & 9 & 10 & 9 & 2 & 3 & 2 & 2 & - & - & 28 & 6 \\
\hline $\begin{array}{l}\text { 25. Sorumlu olmaya } \\
\text { duyarlık }\end{array}$ & 4 & 6 & 2 & 2 & 4 & 4 & 1 & 1 & 3 & 3 & 1 & 1 & 15 & 3 \\
\hline Toplam & 61 & - & 89 & - & 113 & - & 77 & - & 89 & - & 68 & - & 497 & - \\
\hline
\end{tabular}

Not. Yüzdeler en yakın tam sayıya yuvarlanarak sunulmuştur. Sıfıra yakın sayılar yuvarlanmamıştır.

Yukarıdaki Tablo 3’te, incelenen kitaplarda tespit edilen duyarlık kategorilerinin dağılımı frekans ve yüzdeler şeklinde sunulmuştur. Canı Sıkılan Çocuk adlı kitapta insana, insan mutluluğuna duyarlık ( $\mathrm{f}=8$, \%13), okuma kültürüne duyarlık ( $\mathrm{f}=8, \% 13$ ), emeğe ve çalışkanlığa duyarlık ( $\mathrm{f}=6, \% 10)$, dostluk ve arkadaşlığa duyarlık ( $\mathrm{f}=6, \% 10)$, hayvanlara duyarlık ( $\mathrm{f}=5, \% 8)$, aile bireylerine duyarlık ( $\mathrm{f}=5, \% 8)$, doğayaçevreye duyarlık ( $\mathrm{f}=5, \% 8)$, sorumlu olmaya duyarlık ( $\mathrm{f}=4, \% 6)$ yardımlaşmaya duyarlık $(\mathrm{f}=4, \% 6)$, toplumsal huzura duyarlık ( $\mathrm{f}=2, \% 3)$, temizliğe duyarlık ( $\mathrm{f}=2, \% 3)$, paylaşmaya duyarlık $(\mathrm{f}=1, \% 1)$, hakka, hukuka, adalete duyarlık ( $\mathrm{f}=1, \% 1)$, dürüstlüğe duyarlık ( $\mathrm{f}=1, \% 1)$, bilime ve bilimsel düşünceye duyarlık $(\mathrm{f}=1, \% 1)$, geleneksel olana duyarlık ( $\mathrm{f}=1, \% 1)$, zararlı alışkanlıklara karşı duyarlık ( $\mathrm{f}=1, \% 1)$, kategorilerinin aktarılmasına olanak sağlayacak konular yer almaktadır.

Masal Kenti Çocukları adlı kitapta insana, insan mutluluğuna duyarlık (f=15, \%17), sanat ve estetik olana duyarlık ( $\mathrm{f}=12, \% 13)$, emeğe ve çalışkanlığa duyarlık ( $\mathrm{f}=10, \% 11)$, aile bireylerine duyarlık ( $\mathrm{f}=10$, $\% 11$ ), dostluk ve arkadaşlığa duyarlık ( $\mathrm{f}=8, \% 9)$, bilime ve bilimsel düşünceye duyarlık ( $\mathrm{f}=6, \% 6)$, yardımlaşmaya duyarlık ( $\mathrm{f}=5, \% 6)$, toplumsal huzura duyarlık $(\mathrm{f}=4, \% 4)$, doğaya-çevreye duyarlık ( $\mathrm{f}=3$, $\% 3$ ), okuma kültürüne duyarlık ( $\mathrm{f}=3, \% 3)$, umuda-umutlu olmaya duyarlık ( $\mathrm{f}=2, \% 2)$, sorumlu olmaya duyarlık ( $\mathrm{f}=2, \% 2)$, barışa duyarlık $(\mathrm{f}=2, \% 2)$, hayvanlara duyarlık $(\mathrm{f}=2, \% 2)$, kadına duyarlık $(\mathrm{f}=2, \% 2)$, iyilik yapmaya duyarlık ( $\mathrm{f}=1, \% 1)$, yoksul insanlara duyarlık $(\mathrm{f}=1, \% 1)$, hakka, hukuka, adalete duyarlık $(\mathrm{f}=1, \% 1)$ kategorilerinin aktarılmasına olanak sağlayacak konular yer almaktadır.

Hayalet Köy adlı kitapta insana, insan mutluluğuna duyarlık ( $\mathrm{f}=20, \% 18)$, aile bireylerine duyarlık ( $\mathrm{f}=12, \% 11)$, doğaya-çevreye duyarlık $(\mathrm{f}=10, \% 9)$, dostluk ve arkadaşlığa duyarlık ( $\mathrm{f}=10, \% 9)$, okuma kültürüne duyarlık ( $\mathrm{f}=9, \% 8)$, aşka-sevgiye duyarlık ( $\mathrm{f}=7, \% 6)$, geleneksel olana duyarlık ( $\mathrm{f}=6, \% 5)$, yardımlaşmaya duyarlık ( $\mathrm{f}=5, \% 4)$, emeğe ve çalışkanlığa duyarlık ( $\mathrm{f}=5, \% 4)$, yoksul insanlara duyarlık $(f=5, \% 4)$, sorumlu olmaya duyarlık $(f=4, \% 4)$, bilime ve bilimsel düşünceye duyarlık $(f=3, \% 3)$, iyilik yapmaya duyarlık ( $\mathrm{f}=3, \% 3)$, dilsel duyarlık $(\mathrm{f}=3, \% 3)$, temizliğe duyarlık ( $\mathrm{f}=3, \% 3)$, hayvanlara duyarlık $(\mathrm{f}=2, \% 2)$, umuda-umutlu olmaya duyarlık ( $\mathrm{f}=2, \% 2)$, paylaşmaya duyarlık $(\mathrm{f}=2, \% 2)$, kadına duyarlık ( $\mathrm{f}=1$, $\% 1$ ), dürüstlüğe duyarlık (f=1, \%1) kategorilerinin aktarılmasına olanak sağlayacak konular yer almaktadır.

Komşumuz Çok Acayip adlı kitapta aşka-sevgiye duyarlık ( $f=14, \% 18)$, hayvanlara duyarlık ( $f=14$, $\% 18$ ), sanat ve estetik olana duyarlık ( $\mathrm{f}=9, \% 12)$, insana, insan mutluluğuna duyarlık ( $\mathrm{f}=9, \% 12)$, aile bireylerine duyarlık ( $\mathrm{f}=5, \% 6)$, doğaya-çevreye duyarlık $(\mathrm{f}=5, \% 6)$, toplumsal huzura duyarlık $(\mathrm{f}=3, \% 4)$, yardımlaşmaya duyarlık ( $\mathrm{f}=3, \% 4)$, geleneksel olana duyarlık ( $\mathrm{f}=2, \% 3)$, emeğe ve çalışkanlığa duyarlık $(\mathrm{f}=2, \% 3)$, dostluk ve arkadaşlığa duyarlık $(\mathrm{f}=2, \% 3)$, dilsel duyarlık $(\mathrm{f}=2, \% 3)$, paylaşmaya duyarlık $(\mathrm{f}=2$, $\% 3)$, kadına duyarlık ( $\mathrm{f}=1, \% 1)$, hakka, hukuka, adalete duyarlık ( $\mathrm{f}=1, \% 1)$, dürüstlüğe duyarlık ( $\mathrm{f}=1, \% 1)$, 


\section{Gülten Dayığlu Çocuk ve Gençlik Edebiyatı Ödülleri’nde Yılın Romanı Ödülünü Kazanan Eserlerin Duyarlık Eğitimi Açısından İncelenmesi}

temizliğe duyarlık ( $\mathrm{f}=1, \% 1)$, sorumlu olmaya duyarlık ( $\mathrm{f}=1, \% 1)$ kategorilerinin aktarılmasına olanak sağlayacak konular yer almaktadır.

Düşlerin Peşindeki Çocuk adlı kitapta aile bireylerine duyarlık ( $\mathrm{f}=16, \% 18)$, insana, insan mutluluğuna duyarlık ( $\mathrm{f}=11, \% 12)$, iyilik yapmaya duyarlık ( $\mathrm{f}=8, \%)$, doğaya-çevreye duyarlık $(\mathrm{f}=8, \% 9)$, sanat ve estetik olana duyarlık ( $\mathrm{f}=8, \% 9$ ), emeğe ve çalışkanlığa duyarlık ( $\mathrm{f}=8, \% 9)$, geleneksel olana duyarlık ( $\mathrm{f}=7, \% 8$ ), hayvanlara duyarlık ( $\mathrm{f}=6, \% 7)$, yardımlaşmaya duyarlık ( $\mathrm{f}=4, \% 4)$, aşka-sevgiye duyarlık ( $\mathrm{f}=4, \% 4)$, umuda-umutlu olmaya duyarlık ( $\mathrm{f}=3, \% 3)$, sorumlu olmaya duyarlık ( $\mathrm{f}=3, \% 3)$, dostluk ve arkadaşlığa duyarlık ( $\mathrm{f}=2, \% 2)$, yoksul insanlara duyarlık ( $\mathrm{f}=1, \% 1)$ kategorilerinin aktarılmasına olanak sağlayacak konular yer almaktadır.

Yaban Ördeği Ailesinin Göç Yolculuğu doğaya-çevreye duyarlık (f=24, \%35), hayvanlara duyarlık $(\mathrm{f}=13, \% 19)$, insana, insan mutluluğuna duyarlık ( $\mathrm{f}=12, \% 18)$, aşka-sevgiye duyarlık $(\mathrm{f}=4, \% 6)$, aile bireylerine duyarlık ( $\mathrm{f}=3, \% 4)$, umuda-umutlu olmaya duyarlık $(\mathrm{f}=3, \% 4)$, yardımlaşmaya duyarlık $(\mathrm{f}=2$, $\% 3$ ), toplumsal huzura duyarlık ( $\mathrm{f}=2, \% 3)$, paylaşmaya duyarlık $(\mathrm{f}=1, \% 1)$, yoksul insanlara duyarlık ( $\mathrm{f}=1$, $\% 1$ ), geleneksel olana duyarlık ( $\mathrm{f}=1, \% 1)$, iyilik yapmaya duyarlık $(\mathrm{f}=1, \% 1)$, sorumlu olmaya duyarlık ( $\mathrm{f}=1$, \%1) kategorilerinin aktarılmasına olanak sağlayacak konular yer almaktadır.

Genel olarak bakıldığında incelenen kitaplarda en sık insana, insan mutluluğuna duyarlık ( $f=75$, $\% 15)$, doğaya-çevreye duyarlık ( $\mathrm{f}=55, \% 11)$, aile bireylerine duyarlık ( $\mathrm{f}=51, \% 10)$, hayvanlara duyarlık $(\mathrm{f}=42, \% 8)$, emeğe ve çalışkanlığa duyarlık $(\mathrm{f}=31, \% 6)$, sanat ve estetik olana duyarlık $(\mathrm{f}=29, \% 6)$, aşkasevgiye duyarlık ( $\mathrm{f}=29, \% 6)$, dostluk ve arkadaşlığa duyarlık $(\mathrm{f}=28, \% 6)$, yardımlaşmaya duyarlık ( $\mathrm{f}=23$, \%5), okuma kültürüne duyarlık ( $\mathrm{f}=20, \% 4)$ kategorilerine rastlanmıştır. En az ise zararlı alışkanlıklara karşı duyarlık ( $\mathrm{f}=1, \% 0.2)$, barışa duyarlık ( $\mathrm{f}=2, \% 0.4)$, kadına duyarlık ( $\mathrm{f}=4, \% 0.8)$, hakka, hukuka, adalete duyarlık ( $\mathrm{f}=3, \% 0.6)$, dürüstlüğe duyarlık ( $\mathrm{f}=3, \% 0.6)$ kategorileri belirlenmiştir. Toplamda 497 defa duyarlık kategorilerinin tekrar ettiği tespit edilmiştir. Aşağıda, kitaplarda tespit edilen duyarlık kategorileriyle ilgili doğrudan alıntılar açıklanarak sunulmuştur.

Insana, insan mutluluğuna duyarlı: Sen çok iyi bir çocuksun. Tabii ki istediğin saatte çıkabilirsin... Bizim sana güvenimiz tam. Ben sadece senin burada mutlu hissettiğinden emin olmak istiyorum...." (Masal Kenti Çocukları, s.41); "Bunu söylerken güldü. Gözlerini yabancı bir evde açtığından beri ilk kez gülümsüyordu. Zeliha'nın yanında olmaktan keyif alıyor, korkuları biraz olsun hafifliyordu” (Hayalet Köy, s.37); "Pastayı keselim, biz çıkacağız çocuklar. Siz de gönlünüzce eğlenin." (Komşumuz Çok Acayip, s.40). İlk örnekte bir dedenin torununun mutluluğuna verdiği önem okuyucuya sunulmaktadır. İkinci örnekte roman kahramanının nasıl hissettiği, mutluluğu işlenmiştir. Üçüncü örnekte de romanda çocukların iyi vakit geçirerek mutlu olmalarına verilen önem belirtilmektedir. Bu örneklerin insanın mutluluğuna 
verilen önemi yansıtarak okura bunları sezinletebilecek güçte olduğu söylenebilir. Bu sebeple bu örnekler insana, insan mutluluğuna duyarlığı kazandırmada etkili olabilir.

Doğaya-çevreye duyarlık: "Domateslerin çiçek gibi koktuğunu bilmiyordum." dedi Jasmin şaşkknlıkla. (Hayalet Köy, s.36); "Mahalleyi duman bastı, olmaz böyle şey! Çevre kirliliği yaratıyorsunuz. Belediyeye şikâyet edeceğim." (Komşumuz Çok Acayip, s.96); "Bu filtreler zehirli gazları emiyor, doğa da bundan etkilenmiyordu." (Yaban Ördeği Ailesinin Göç Yolculuğu, s.41). Birinci örnekte bir bitkinin kokusundan bahsedilerek çocuklara doğada keşfedebilecekleri bir bilgi sunulmaktadır. İkinci ve üçüncü örnekte doğanın tahrip edilerek çevre kirliliği yaratılması olay örgüsünde işlenmektedir. Böylelikle çocuklar insanların yanlış davranışları ile çevreye verdiği zararların nelere yol açabileceği konusunda bilgi sahibi olabilir. Bu sebeple örnekler, doğaya-çevreye duyarlığı geliştirebilecek niteliktedir.

Aile bireylerine duyarlık: "Klzım! Mis kokulu yavrum! Hadi aç da göreyim o güzel gözlerini. Anan kurban olsun sana, çok korkuttun bizi, çok...” (Hayalet Köy, s. 15); "Tamam kendisini birakabilirlerdi belki, ama ya babası?" (Komşumuz Çok Acayip, s.83); “Sen de çok özel bir büyükannesin büyükanne." (Düşlerin Peşindeki Çocuk, s.13). İlk örnekte bir annenin kızına verdiği önem, ikinci örnekte aile bireylerinin düşünülmesi, üçüncü örnekte de kahramanın büyükannesine olan sevgisi aktarılmıştır. Bu tür örnekler yoluyla kahramanlara öykünen çocuk, aile bireylerine duyarlı olmanın değerini kavrayarak kendi hayatına yansitabilir.

Hayvanlara duyarlık: “... Memo gülerek kediyi kucağına alıp tüylerini okşamaya başladı.” (Canı Sıkılan Çocuk, s.33); “Ama torbadaki tavuk kemiklerini, pilav artıklarını kedilere vermeden eve dönmek istemiyordu." (Komşumuz Çok Acayip, s.59); “Onların üşümesi hayvanların evsiz kalması demekti. Çünkü bu yiyeceklerin de azalması anlamına geliyordu. Artık sıcak bir yuvaya göç etmeleri kaçınllmazdı. Kış onları da bu topraklardan kovacaktı." (Yaban Ördeği Ailesinin Göç Yolculuğu, s.8). Yukarıda verilen üç örnekte hayvanların sevilmesi, yiyecek bulmalarına yardım edilmesi, yaşadıkları zorluklar olay örgüsünde çocuğa sunulmaktadır. Buradaki eylemlere öykünecek çocukların da hayvanlara duyarlık kazanmaları olağan bir durumdur.

Emeğe ve çalışkanlığa duyarlık: "Ne kadar çok toplamışsın! Aferin sana Ördekayak! Bunlar sayesinde büyükannen birkaç güne kalmaz ayağa kalkar artık.” (Düşlerin Peşindeki Çocuk, s.29); “... Ne dediyse hepsini yapmıştı. Kalan yemekleri bile tel dolaba yerleştirmişti. Şimdi sıra üstüne kuru bir şeyler giymeye gelmişti." (Hayalet Köy, s.50); "Sevgili oğlum Pergamos'u bu karışılk ortamdan uzaklaşmast ve eğitimine devam edebilmesi için, er bakımdan iyi yetişeceğinden emin olduğum memleketime göndermeye karar verdim." (Masal Kenti Çocukları, s.23). Yukarı sunulan örneklerin birincisinde kahramanın emek vererek çalışmasının olumlu sonucu olacağı okura sunulmuştur. İkinci örnekte kahramanın emek vererek ev işlerine yardım etmesinin değeri okura verilmek istenmektedir. Üçüncü örnekte de bir annenin oğlunun eğitimine verdiği önem belirtilmektedir. Bu sebepler doğrultusunda verilen örneklerin emeğe ve çalışkanlığa duyarlık konusunda etkili olacağı düşünülmektedir.

Sanat ve estetik olana duyarlık: "Athena Tapınă̆ı!” diye bağırdı coşkuyla birden. "Düşlerimdekinden bile daha görkemli. Tipkı beyaz bir gül gibi!” (Masal Kenti Çocuklarl, s.9); "Çünkü 


\section{Gülten Dayığlu Çocuk ve Gençlik Edebiyatı Ödülleri’nde Yılın Romanı Ödülünü Kazanan Eserlerin Duyarlık Eğitimi Açısından İncelenmesi}

yaptı̆̆ şeyin sanat değeri taşıması için bu ilkelliğe ihtiyacı vardı. Ateş mi insanı insan mı ateşi biçimlendirmişti bunu anlatacaktı vazolarıyla, çanaklarlyla." (Komşumuz Çok Acayip, s.98). İlk örnekte, kültürel bir mirasın değeri bir benzetme yapılarak işlenmiştir. İkinci örnekte de romandaki bir kişinin sanatsal bakışla oluşturmaya çalıştığı ürünlerden bahsedilmiştir. Örneklerdeki anlatımın akışına kapılan çocuk sanat ve estetiğe verilen duyarlığı kazanabilir.

Aşka-sevgiye duyarlık: "Yine de Kemik Aziz'in yüreği babasından iyiydi, çünkü sevmeyi bilirdi." (Komşumuz Çok Acayip, s.7); "Keşke dünyamızı da insanları da, kardelen gibi tertemiz, saf, menfaate dayanmayan bir sevgiyle sevebilsek... Her şey ne güzel olurdu." (Hayalet Köy, s. 79). Bu örneklerde sevginin önemi, kişilerarası bağların samimiyeti çocuklara aktarılmaktadır. Böylelikle sevginin anlamını düşünebilen çocukta bu alana duyarlık oluşabilir.

Dostluk ve arkadaşlı̆̆a duyarlık: "Ördekayak, ertesi sabah Çömlekel'e dostluğu, misafirperverliği ve ona öğrettiği şeyler için teşekkür etti." (Düşlerin Peşindeki Çocuk, s.82); "O sabah dört arkadaş, gimnazyum hala kapalı olmasına rağmen erkenden buluştular. Hastalıktan kurtulduklarından beri ilk kez bir araya geliyorlarlardı. Birbirlerine anlatacak o kadar çok şeyleri vardı ki..." (Masal Kenti Çocukları, s.134). Yukarıdaki örneklerde arkadaşlar arasındaki bağlar ve iletişim aktarılmıştır. Arkadaşlığa verilen önemin böylelikle çocuk tarafindan sezinlenmesine olanak sağlanacağı bu örnekler dostluk ve arkadaşlığa duyarlık kategorisinde değerlendirilmiştir.

Yardımlaşmaya duyarlık: "Yardım edelim mi eşyaların taşınmasına, hem kedileri de söyleriz." (Komşumuz Çok Acayip, s. 18); "Köylüler, yolları olsun diye yıllarca çok uğraştı. Her seçim döneminde umutlandık. Kime oy verdiysek, seçildiğinde bizi unuttu. Baktık olmuyor, imece usulü yapalım dedik." (Hayalet Köy, s.57). İlk örnekte romandaki kahramanların bir eşya taşımaya yardım etmeye olan gönüllülükleri, ikinci örnekte de köylülerin yardımlaşarak yok yapmaları işlendiği için bu örnekler yardımlaşmaya duyarlı̆̆ 1 geliştirecek nitelikte değerlendirilmiştir.

Okuma kültürü̈ne duyarlık: "Herkes yanında oturduğu sıra arkadaşıyla birlikte bir kitap okuyacak. Okuduğunuz kitabı aranızda tartışıp ana fikrini sınıfta birlikte anlatacaksınız." (Canı Sıkılan Çocuk, s.14); "Kral II. Eumenes; şairleri, tarihçileri ve düşünürleri yeni eserler yazmaya, daha sonraki kuşakların onları ve düşüncelerini tanımaları için yapıtlarını Asya kıtasının bu ilk kütüphanesine bağışlamalarına teşvik ederdi." (Masal Kenti Çocuklarl, s.15). Birinci örnekte romanda ders esnasında kitap okumaya verilen önemden bahsedilmiştir. İkinci örnekte ise Pergamon antik kentindeki macerada kütüphane oluşturulmasının önemi verilmiştir. $\mathrm{Bu}$ sebeplerden belirtilen örnekler okuma kültürüne duyarlık kategorisine alınmıştır. 
Geleneksel olana duyarlık: "Mezara yerleştirilen halanın üzerine geleneklere göre herkes birer kürek toprak atıyordu.” (Komşumuz Çok Acayip, s.21); “... Birçoğunuzun aile fertlerinizle de, arkadaşlarınızla da arası kötüymüş. Büyüklerinizle ve birbirinizle yaptığınız saygısız konuşmalarla kavgaları duyunca, öğretmeniniz olarak çok utandım." (Canı Sıkılan Çocuk, s.13). Yukarıdaki ilk örnekte bir geleneğin uygulanması, ikinci örnekte de saygısızlık yapmanın uygunsuzluğundan bahsederek geleneksel olana duyarlık kategorisi işlenmiştir.

Sorumlu olmaya duyarlık: "Doğum yeri kuzey ormanları olan bu sevimli ördekler çoktan büyümüş, uçmayı ögrenmiş, artık kendi işlerini kendileri görebilir hale gelmişlerdi.” (Yaban Ördeği Ailesinin Göç Yolculuğu, s.8); "Ne olursa olsun, söylenen bir selamı bile sahibine iletmelisin.” (Düşlerin Peşindeki Çocuk, s.62). Yukarıdaki örneklerde kendi işlerini yapmanın ve selam iletmenin bile bir sorumluluk gerektirdiği belirtilerek sorumlu olmaya duyarlık işlenmiştir.

İyilik yapmaya duyarlık: "Jasmin, içinden binlerce teşekkür yolladı Zeliha'ya. Birden, yaptıkları güzel şeyler için dadıslyla hizmetçilere hiç teşekkür etmediği geldi aklına." (Hayalet Köy, s.60). Örnek ile iyilik yapma ve iyiliğe verilen cevabın önemi işlenmiştir. Böylelikle çocuklar iyilik yapmaya duyarlık kazanabilir.

Toplumsal huzura duyarlık: "Çekiyor da komşular beni çekemiyor. Yani anlayacağın dumandan şikayetçiler. Bacayı yükseltelim diyorum, duman onlara değil havaya doğru gitsin." (Komşumuz Çok Acayip, s.115). Örnekte diğer insanlara rahatsızlık yaşatan bir durumun işlenmesi ile çocuklar toplumsal yaşamda uymaları gereken kuralları kavrayarak toplumsal huzura duyarlık geliştirebilir.

Umuda-umutlu olmaya duyarlık: “... Inanmayanlar $d a$, çabalamayanlar da, dertleriyle kalakalır!” (Düşlerin Peşindeki Çocuk, s.38). Örnekte hayaller için umutlu bir şekilde çabalamanın önemi vurgulanmaktadır. Bu sebeple durum, umuda-umutlu olmaya duyarlık olarak değerlendirilmiştir.

Bilime ve bilimsel düşünceye duyarlık: "Bir başka havluyu koltuk altlarında ve vücudunda gezdirdi. Hekim Gelos, ateşi düşürmenin en etkili yolunun soğuk su masajı olduğunu söylemişti." (Masal Kenti Çocukları, s.122). Bu örnekte, romandaki hekimin bilimsel uygulamasına dikkat çekilmiştir. Böylelikle çocuklar bilimsel bilginin uygulama alanını sezinleyerek duyarlık kazanabilir.

Yoksul insanlara duyarlık: "Çünkü bu ülkelerde yaşayan insanlar yoksul ve güçsüz. O aletleri üreten ülkelerle başa çıkamıyorlar da ondan.” (Yaban Ördeği Ailesinin Göç Yolculuğu, s.13). Bu örnek, yoksul bir ülkenin durumunu ve ektilerini yaşam gerçekliği içerisinde çocuğa sunduğu için yoksul insanlara duyarlık kategorisinde değerlendirilmiştir.

Paylaşmaya duyarlık: "Hırkamı çıkarıp bulduğum meyveleri içine doldurdum. Demek ki bu öğle yemeğinde yine bögürtlen yiyecektik." (Canı Sikılan Çocuk, s.59). Roman kahramanının maceraları sırasında öğle yemeği toplayarak bunu arkadaşı ile paylaşmak istemesinin ele alınması bu kategoriye uygun görülmüştür.

Temizliğe duyarlık: "Burayı leş gibi bırakıp gitmeyin, pisliğinizi temizleyin tamam mı?" (Komşumuz Çok Acayip, s.41). Örnekte kirletilen bir yerin temizlenmesinin yapılması gereken bir davranış 


\section{Gülten Dayığlu Çocuk ve Gençlik Edebiyatı Ödülleri’nde Yılın Romanı Ödülünü Kazanan Eserlerin Duyarlık Eğitimi Açısından İncelenmesi}

olduğu kahramanlar aracılığı ile aktarılmaktadır. Böylelikle temizliğe duyarlık kategorisi için uygun bir örnektir.

Dilsel duyarlık: “... Kusura bakma Zeliha abla, ben İngilizcesi yerine Türkçesini yeğlerim.” (Hayalet Köy, s.87). Burada kahramanın Türkçe duyarlığını belirtmesi ile dilsel duyarlık edinilmesine olanak sağlanmaktadır.

Kadına duyarlı: "Pergamos, özellikle Pergamon kadınlarının sokaklarda böylesine rahat ve kaygısız dolaşmasına çok şaşırmıştı. Pergamon'da kadınların Girit'tekilerden farklı olarak toplumsal hayata katıldı̆̆ını biliyordu, ama yine de kadınların zenginleştirdiği yaşamı solumak garip bir heyecan veriyordu ona." (Masal Kenti Çocukları, s.20). Örnekte bir toplum içerisinde kadınların eşit haklara sahip olmasının değeri vurgulanarak kadına duyarlık aktarılmaktadır.

Hakka, hukuka, adalete duyarlı: “... Polise fabrikanın adını söyler söylemez sorun çözüldü. Meğer bu şirketin atıkları ormana gömdüğü anlamışlar; bir süredir takip ediyorlarmış." (Canı Sikılan Çocuk, s.85). Bu örnek ile bir suç unsurunu polise bildirmenin en iyi çözüm olacağı belirtilerek hakka, hukuka, adalete duyarlık desteklenmektedir.

Dürüstlï̆ğe duyarlı: "Korkma oğlum, işin doğrusu neyse anlatırız, serbest bırakırlar merak etme." (Komşumuz Çok Acayip, s.81). Alıntıda dürüst bir şekilde davranmanın olumsuz bir olayı çözmede etkisi vurgulanarak dürüstlüğe duyarlık aktarılmaktadır.

Barışa duyarlık: "Sizce, oyun biraz oyun olduğu için biraz abartmış olabilirler mi? Ben hiçbir toplumun insani değerleri böylesine bir tarafa bırakıp savaşmaya bu derece odaklanabileceğine inanamıyorum." (Masal Kenti Çocukları, s.34). Örnekte, insani değerlere vurgu yapılarak barışa duyarlığa değinilmektedir.

Zararlı alışkanlıklara karşı duyarlık: "Bilgisayar oyunlarını yine seviyorum. Ama artık bilgisayarın başında eskisi kadar çok zaman geçirmiyorum." (Canı Sıkılan Çocuk, s.92). Bu örnekte kahramanın kitaptaki olay örgüsü sonucu değişen bir alışkanlığı dile getiriliyor. Böylelikle romana eşlik eden çocuklar değişimi anlamlandırarak özümseyebilir.

Aşağıda, inceleme sonucunda tespit edilen duyarlık kategorileri kitaplara göre görselleştirilerek sunulmuştur. 


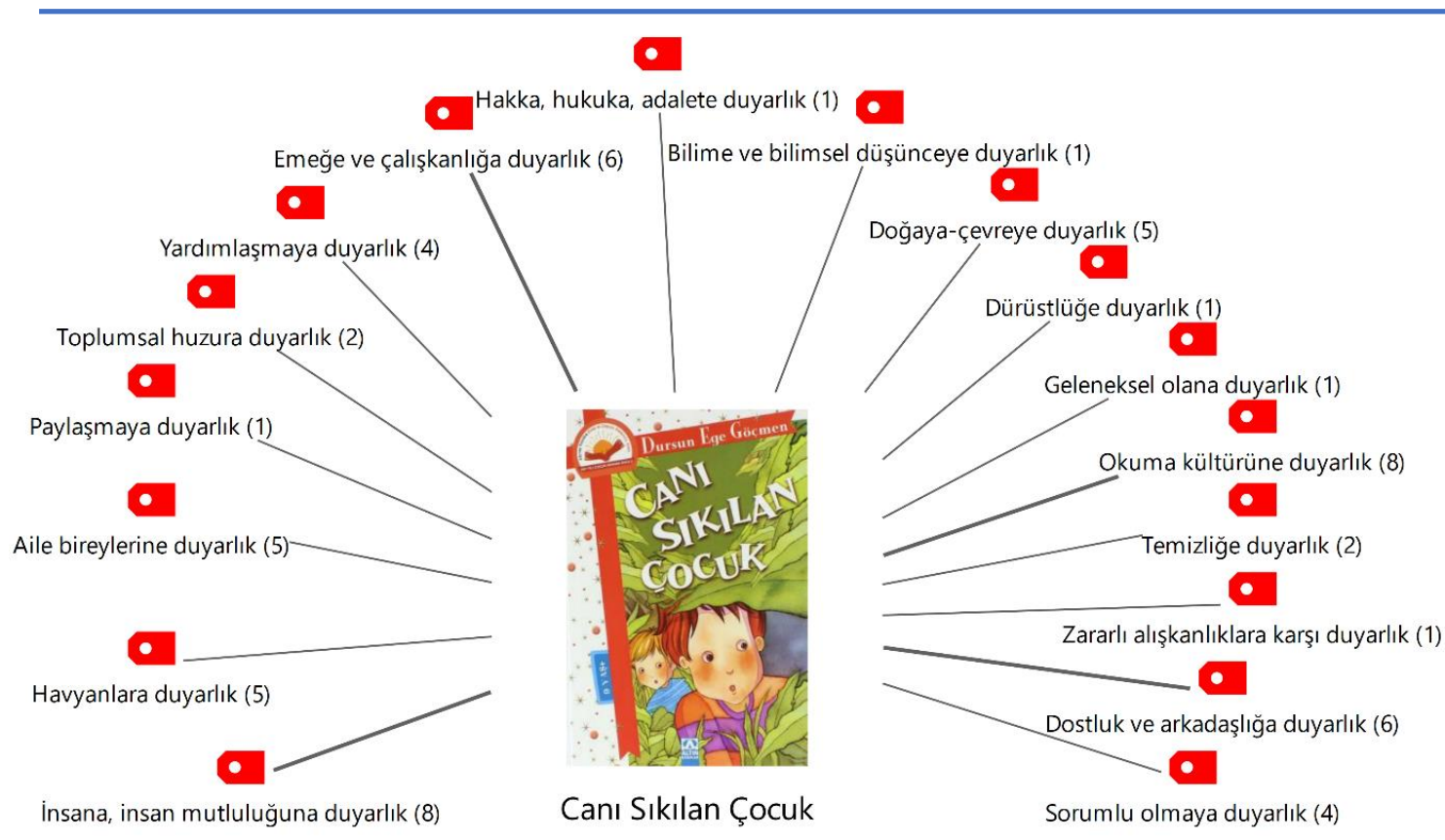

Görsel 1. Canı Sıkılan Çocuk adlı kitaba ilişkin bulgular.

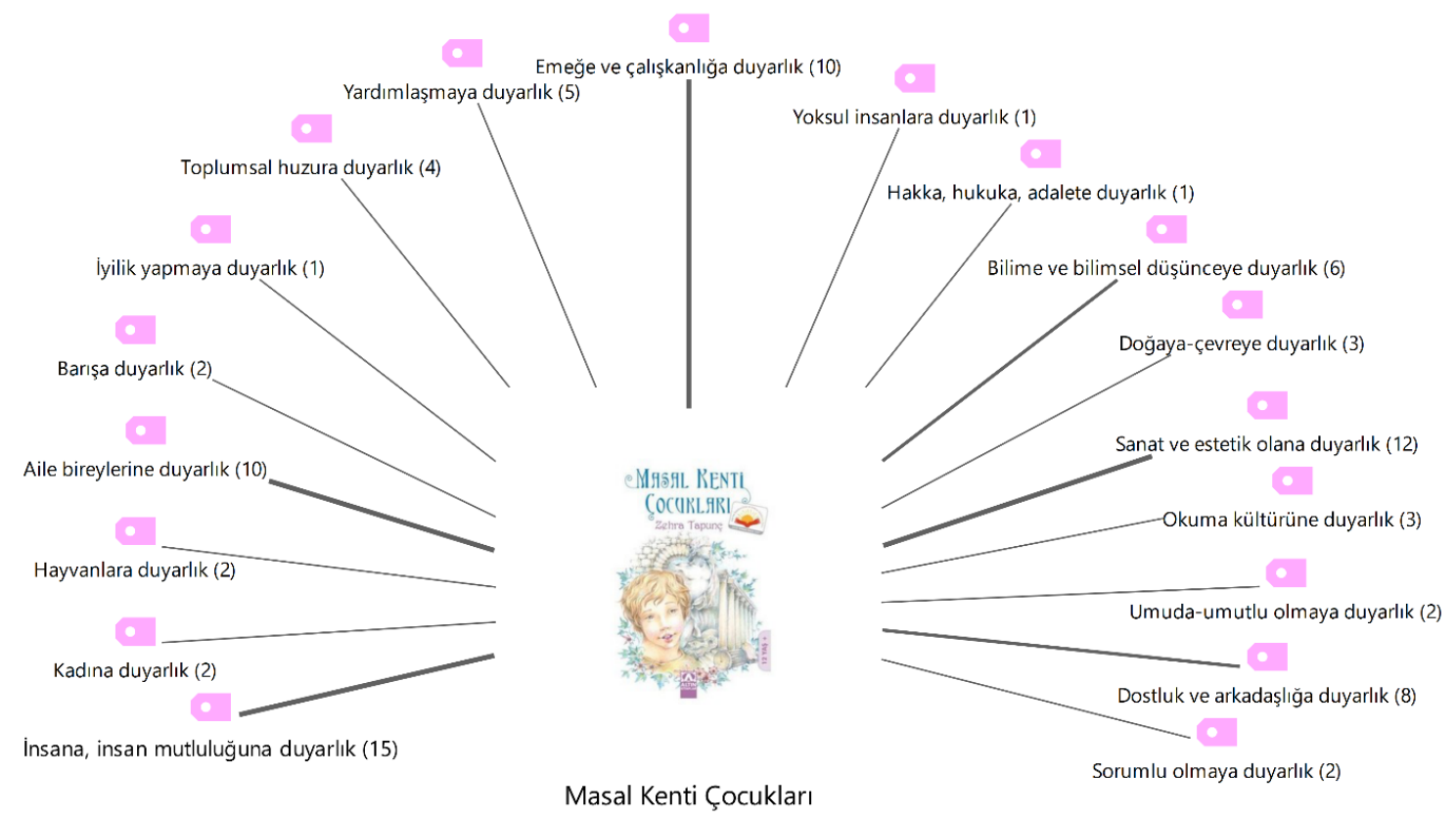

Görsel 2. Masal Kenti Çocukları adlı kitaba ilişkin bulgular. 


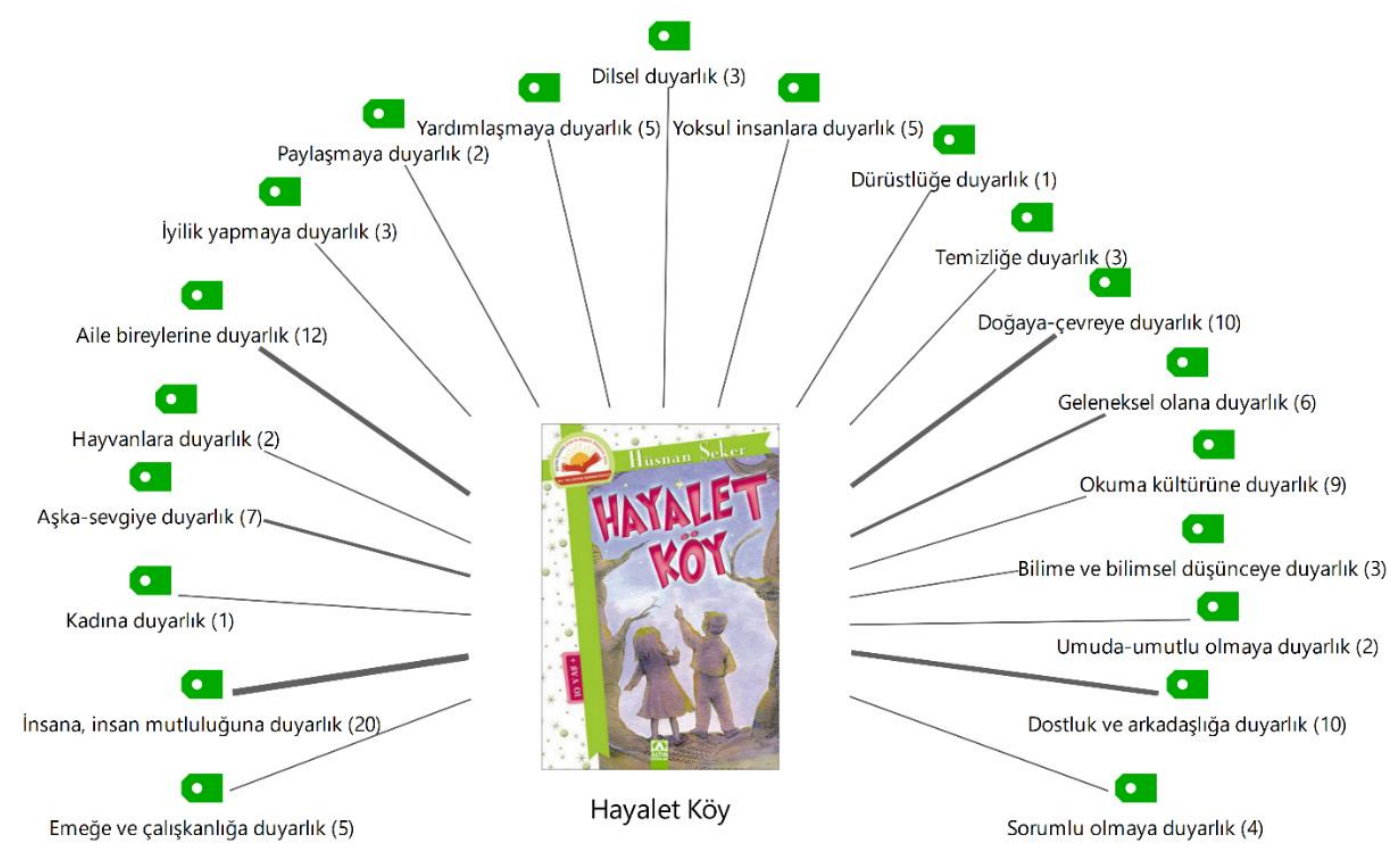

Görsel 3. Hayalet Köy adlı kitaba ilişkin bulgular.

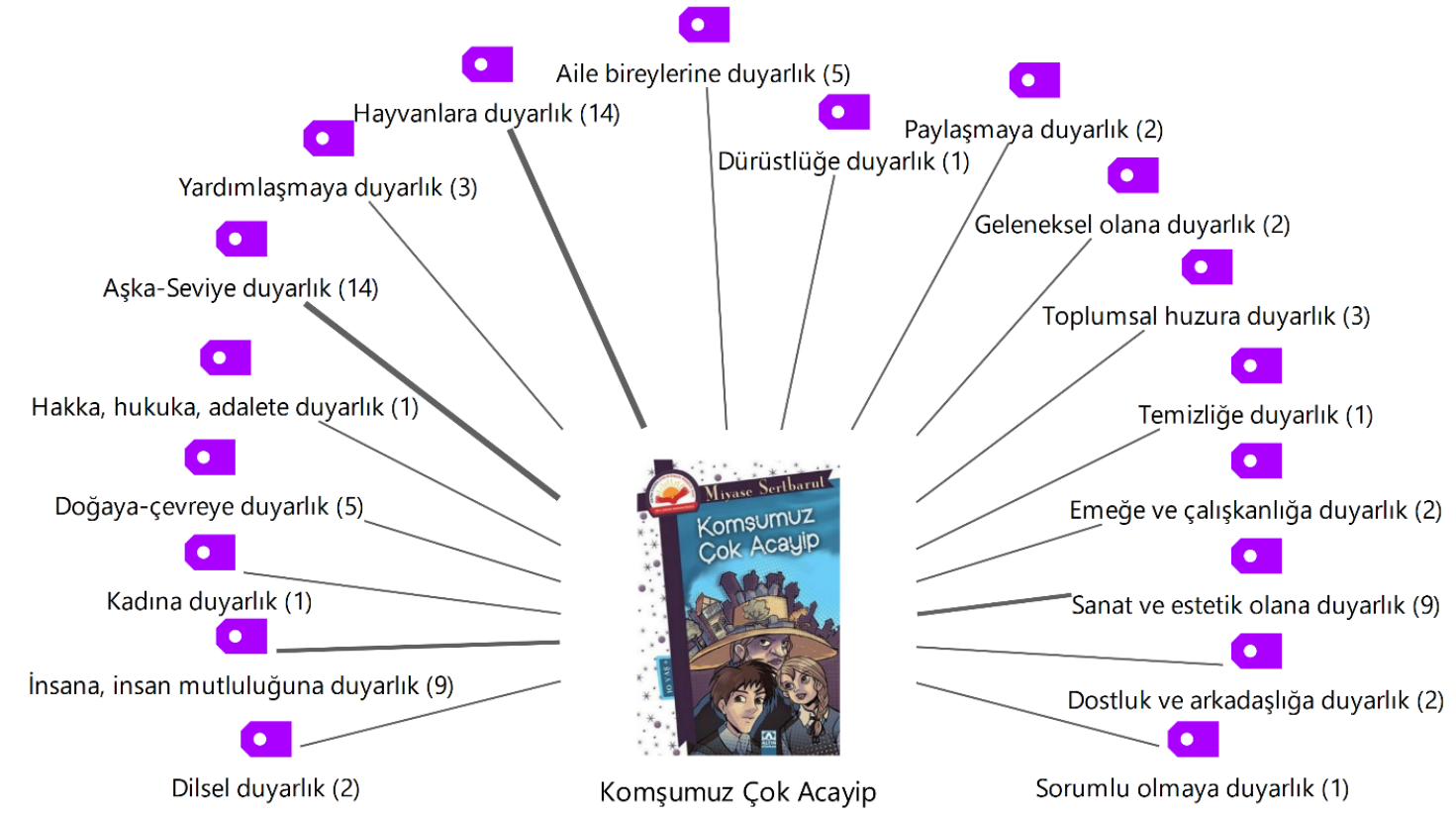

Görsel 4. Komşumuz Çok Acayip adlı kitaba ilişkin bulgular. 


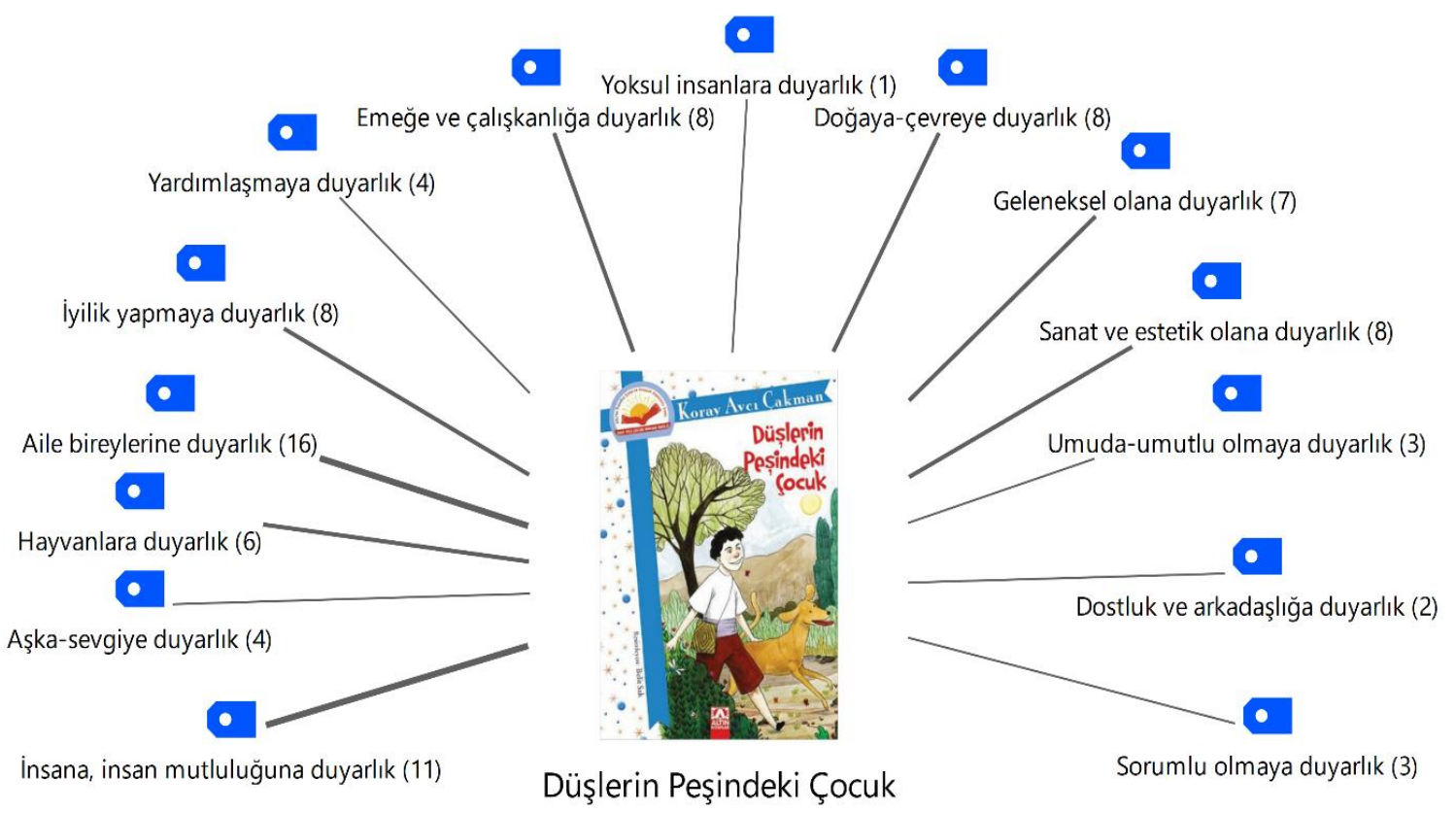

Görsel 5. Düşlerin Peşindeki Çocuk adlı kitaba ilişkin bulgular

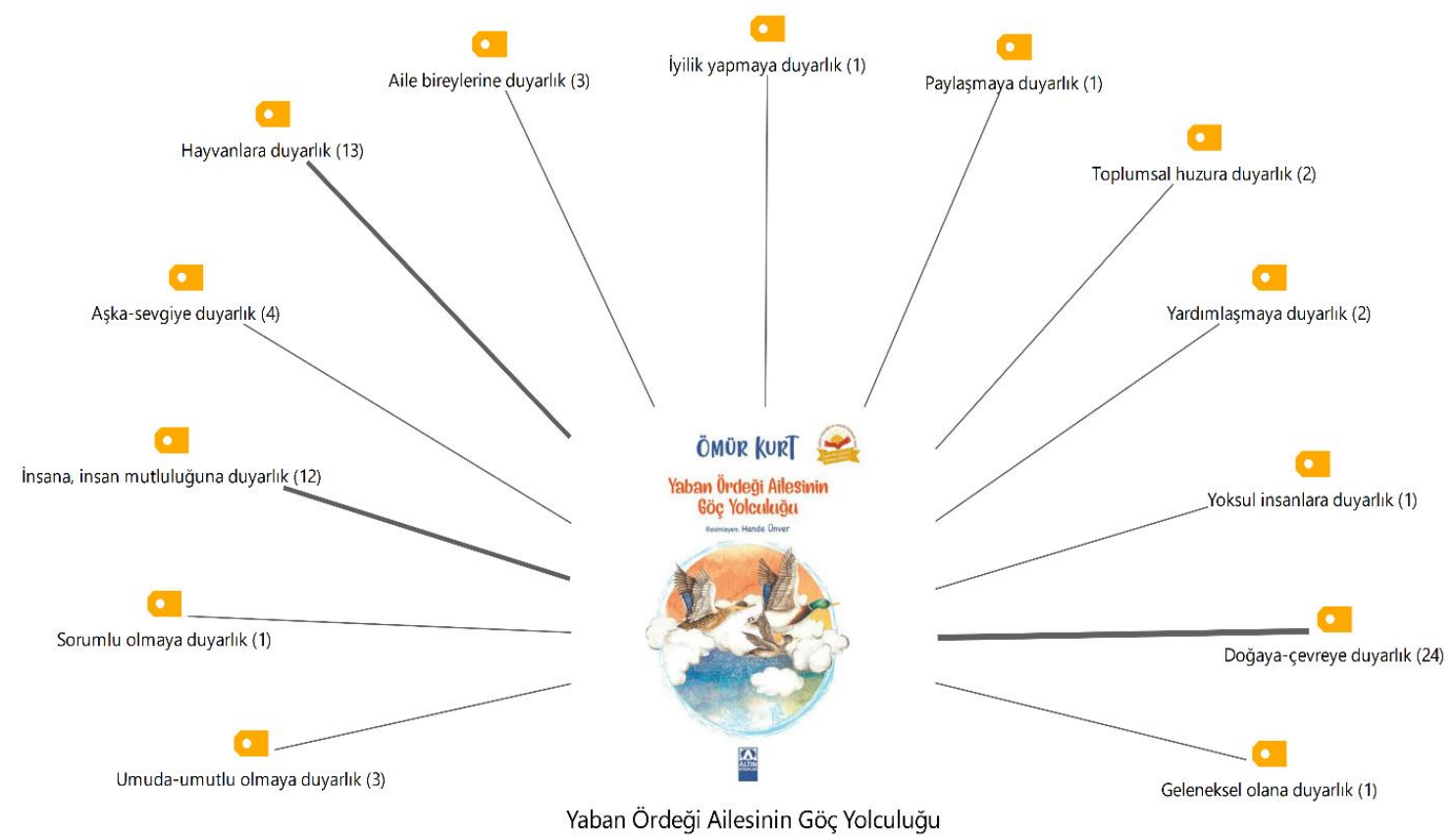

Görsel 6. Yaban Ördeği Ailesinin Göç Yolculuğu adlı kitaba ilişkin bulgular

\section{Tartışma ve Sonuç}

Çalışmada, Gülten Dayıoğlu Çocuk ve Gençlik Edebiyatı Ödülleri’nde yılın çocuk romanı seçilen Canı Sıkılan Çocuk, Masal Kenti Çocukları, Hayalet Köy, Komşumuz Çok Acayip, Düşlerin Peşindeki Çocuk, Yaban Ördeği Ailesinin Göç Yolculuğu adlı kitaplar duyarlık eğitimi açısından incelenmiştir.

İncelemeye alınan kitaplara genel olarak bakıldığında tüm duyarlık kategorilerine farklı oranlarda rastlandığı anlaşılmaktadır. Kitaplarda incelenen duyarlık kategorileri toplam 497 kez tekrar etmiştir. Bu duyarlık kategorilerinin dağılımı şu şekildedir: insana, insan mutluluğuna duyarlık ( $f=75, \% 15)$, doğaya- 
çevreye duyarlık $(\mathrm{f}=55, \% 11)$, aile bireylerine duyarlık $(\mathrm{f}=51, \% 10)$, hayvanlara duyarlık $(\mathrm{f}=42, \% 8)$, emeğe ve çalışkanlığa duyarlık ( $\mathrm{f}=31, \% 6)$, sanat ve estetik olana duyarlık ( $\mathrm{f}=29, \% 6)$, aşka-sevgiye duyarlık ( $\mathrm{f}=29$, \%6), dostluk ve arkadaşlığa duyarlık ( $\mathrm{f}=28, \% 6)$, yardımlaşmaya duyarlık ( $\mathrm{f}=23, \% 5)$, okuma kültürüne duyarlık ( $\mathrm{f}=20, \% 4)$, geleneksel olmaya duyarlık $(\mathrm{f}=17, \% 3)$, sorumlu olmaya duyarlık $(\mathrm{f}=15, \% 3)$, iyilik yapmaya duyarlık ( $\mathrm{f}=13, \% 3$ ), toplumsal huzura duyarlık ( $\mathrm{f}=11, \% 2)$, bilime ve bilimsel düşünceye duyarlık $(\mathrm{f}=10, \% 2)$, umuda-umutlu olmaya duyarlık $(\mathrm{f}=10, \% 2)$, yoksul insanlara duyarlık $(\mathrm{f}=8, \% 2)$, iyilik yapmaya duyarlık ( $\mathrm{f}=6, \% 1)$, temizliğe duyarlık $(\mathrm{f}=6, \% 1)$, dilsel duyarlık $(\mathrm{f}=5, \% 1)$, kadına duyarlık $(\mathrm{f}=4, \% 0.8)$, dürüstlüğe duyarlık ( $\mathrm{f}=3, \% 0.6)$, hakka, hukuka, adalete duyarlık $(\mathrm{f}=3, \% 0.6)$, barışa duyarlık $(\mathrm{f}=2, \% 0.4)$, zararlı alışkanlıklara karşı duyarlık ( $f=1, \% 0.2)$ kategorilerine rastlanmıştır. Bu şekilde, kitaplarda en sık insana, insan mutluluğuna duyarlık, aşka-sevgiye duyarlık, hayvanlara duyarlık, aile bireylerine duyarlık, emeğe ve çalışkanlığa duyarlık, doğaya-çevreye duyarlık, sanat ve estetik olana duyarlık, okuma kültürüne duyarlık, dostluk ve arkadaşlığa duyarlık alanlarına yer verildiği görülmektedir. Buna göre incelenen kitapların daha çok bu duyarlık alanlarında okuyucuları farkında kılabileceği düşünülmektedir. Böylelikle bu kitapların eğitim öğretim sürecinde okutulması çocukları genel anlamda hayata duyarlı kılmaya fayda sağlayabilir. Bu kitapların seçici kurul tarafından yılın romanı olarak belirlenmesi kitapların çocuk edebiyatının temel ögelerini yansıtan nitelikli yapıtlar olduğu olarak yorumlanabilir. Bu nitelikli yapıtlar ile çocuklar hayatlarında karşılarına çıkabilecek durumlara, kişilere, canlılara duyarlı bireyler haline getirilebilir.

Karagöz, Sezer ve Sarman (2019) tarafindan yapılan ve Necati Güngör'ün çocuk öykülerinin incelendiği çalışmada insan ve insan mutluğuna, aile bireylerine, hayvanlara, aşka-sevgiye, doğaya, okuma kültürüne, emeğe ve çalışmaya duyarlık kategorilerine sıkça yer verildiği sonucuna ulaşılmıştır. Karakuş Tayşi (2019) ise Sevim Ak'ın öykülerini duyarlık açısından incelediği çalışmasında insan ve insanın mutluluğu, dilsel, aile bireylerine, aşka-sevgiye, hayvanlara, yardımlaşmaya, doğaya, dürüst olmaya karş1 duyarlık alanlarının sık ele alındığını saptamıştır. Evsen'in (2019) çalışmasında Mustafa Ruhi Şirin'in şiir ve masallarında en fazla hayal ve düş gücüne duyarlık içeren ögeler tespit edilmiştir. Çalışmada şiir ve masalların incelenmesi sebebiyle hayal ve düş gücüne duyarlığın işlenmesi tür özellikleri açısından olağan bir sonuç olarak değerlendirilebilir. Etoğlu Kibris (2019) tarafından hazırlanan çalışmada Gülten Dayığlu'nun kitaplarında en sık insana ve insanın mutluluğuna, insani özelliklere, doğaya, aile bireylerine, aşka-sevgiye, hayvanlara, yardımlaşmaya, dürüst olmaya karşı duyarlık kategorilerine rastlanmıştır. Konuyla ilgili hazırlanan çalışmalara bakıldığında, elde edilen duyarlık kategorileri açısından bu araştırma ile benzerlikler bulunduğu görülmektedir. Karakuş Tayşi (2019) tarafından yürütülen çalışma, dilsel duyarlık ve dürüst olmaya karşı duyarlık kategorilerine ilişkin konuların fazla olması açısında bu araştırmadan farklılaşmaktadır. 
Canı Sıkılan Çocuk adlı kitapta en fazla insana, insan mutluluğuna duyarlık, hayvanlara duyarlık, aile bireylerine duyarlık, emeğe ve çalışkanlığa duyarlık, doğaya-çevreye duyarlık, okuma kültürüne duyarlık, dostluk ve arkadaşlığa duyarlık kategorilerine ilişkin konulara yer verilmiştir. Bu eserde çocuklar iki arkadaşın macerasına ortak olarak belirtilen duyarlık kategorilerini içeren konuları görebilirler.

Masal Kenti Çocukları adlı kitapta en fazla insana, insan mutluluğuna duyarlık, aile bireylerine duyarlık, emeğe ve çalışkanlığa duyarlık, sanat ve estetik olana duyarlık, dostluk ve arkadaşlığa duyarlık kategorileri hakkında farkındalık oluşturabilecek konular tespit edilmiştir. Bu kitap ile çocuklar, tarihi bir kentteki dört arkadaşın macerasını onlarla yaşayarak belirtilen duyarlık alanları sezinleyebilirler.

Hayalet Köy adlı kitapta çocukları en fazla insana, insan mutluluğuna duyarlık, aile bireylerine duyarlık, doğaya-çevreye duyarlık, okuma kültürüne duyarlık, dostluk ve arkadaşlığa duyarlık kategorileri ile karşılaştıracak konulara rastlanmıştır. Bu kitapta bir çocuğun kendini keşfetme ve zararlı duygulardan arınması konu edilerek duyarlıklar ile ilgili konular sunulmuştur.

Komşumuz Çok Acayip adlı kitapta en fazla insana, insan mutluluğuna duyarlık, aşka-sevgiye duyarlık, hayvanlara duyarlık, sanat ve estetik olana duyarlık kategorilerini yansıtan konulara yer verildiği saptanmıştır. Bu eserde söz konusu duyarlık kategorileri, mahallelinin ve mahalleye yeni taşınan bir kadının hikâyesi anlatılarak aktarılmaktadır.

Düşlerin Peşindeki Çocuk adlı kitapta en fazla insana, insan mutluluğuna duyarlık, aile bireylerine duyarlık, iyilik yapmaya duyarlık, emeğe ve çalışkanlığa duyarlık, doğaya-çevreye duyarlık, geleneksel olana duyarlık, sanat ve estetik olana duyarlık kategorilerini aktarmaya yönelik konular tespit edilmiştir. Kitap adından da görüldüğü gibi düşlerin peşinde bir çocuğun maceraları ile belirtilen duyarlık kategorileri işlenmiştir.

Yaban Ördeği Ailesinin Göç Yolculuğu adlı kitapta en fazla insana, insan mutluluğuna duyarlık, hayvanlara duyarlık, doğaya-çevreye duyarlık kategorilerine ilişkin konulara yer verildiği saptanmıştır. Kitapta, göç mevsimi yaklaşmasına rağmen henüz yavruları yumurtadan çıkmadığı için göç edemeyen yaban ördeği ailesinin kış mevsimindeki göç macerası ile duyarlık kategorileri işlenmiştir.

Ayrıca, incelenen duyarlık kategorileri ile ilgili konuların \%12.27'si (f=61) Canı Sıkılan Çocuk; \%17.9’u (f=89) Masal Kenti Çocuklar1; \%22.73'ü (f=113) Hayalet Köy; \%15.49’u (f=77) Komşumuz Çok Acayip; \%17.9’u (f=89) Düşlerin Peşindeki Çocuk; \%13.68’i (f=68) Yaban Ördeği Ailesinin Göç Yolculuğu adlı kitapta tespit edilmiştir. Buna göre en fazla sayıda duyarlık konusu Hayalet Köy, en az sayıda duyarlık konusu da Yaban Ördeği Ailesinin Göç Yolculuğu adlı kitapta bulunmaktadır.

Araştırmanın sonuçlarına göre aşağıdaki öneriler sunulabilir.

1. Duyarlık eğitimi konusunda öğretmen ve ebeveynler bilgilendirilebilir. Böylelikle çocukları çeşitli konularda duyarlı kılacak nitelikli kitaplara ulaşmak daha olası hale gelir.

2. Kazandırılması hedeflenen duyarlık kategorilerine uygun kitaplar, yapılan araştırmalarda ulaşılan sonuçlara göre seçilebilir. 


\section{Gülten Dayığlu Çocuk ve Gençlik Edebiyatı Ödülleri’nde Yılın Romanı Ödülünü Kazanan Eserlerin Duyarlık Eğitimi Açısından İncelenmesi}

3. Farklı yaş grupları ve farklı türlerdeki eserler de duyarlık eğitimi açısından incelenerek eserler arası karşılaştırma yapmaya olanak sağlanabilir.

\section{Kaynaklar}

Alemdar, S. G. ve Süngü, A. (2017). Nazım Hikmet'in Sevdalı Bulut adlı kitabındaki masalların duyarlık eğitimi bağlamında incelenmesi. T. Şimşek ve B. V. Yıldız (Ed.), IV. Uluslararası Çocuk ve Gençlik Edebiyatı Sempozyumu içinde (s. 301-314). İstanbul: Step Matbaacılık.

Aslan, C. (2013). Duyarlık ve düşünceyi geliştirmede çocuk/gençlik edebiyatı. Çoluk Çocuk Anne Baba Ë̆itimci Dergisi, (12), 29-32.

Aslan, C. (2016). Oğuz Tansel'in derleyip yazdığı masalların duyarlık eğitimi bağlamında incelenmesi. S. Sever ve S. Karagül (Ed.), Uluslararası Türk Masal Dünyası ve Doğumunun Yüzüncü Yılında Ŏguz Tansel Sempozyumu içinde (s. 131-152). Ankara: Ankara Üniversitesi Çogem, Odtü.

Aslan, C. (2019). Çocuk edebiyatı ve duyarlık eğitimi. Ankara: Pegem Akademi Yayıncılık.

Dilidüzgün, S. (1996). Çağdaş çocuk yazını. İstanbul: Yapı Kredi Yayınları.

Etoğlu Kibris, P. (2019). Çocuk edebiyatı eserlerinin duyarlı eğitimi bağlamında incelenmesi: Gülten Dayıoğlu örneği (Yayımlanmamış yüksek lisans tezi). Kütahya Dumlupınar Üniversitesi, Eğitim Bilimleri Enstitüsü, Kütahya.

Evsen, K. (2019). Mustafa Ruhi Şirinin çocuk şiirleri ve masallarının duyarlık eğitimi açısından incelenmesi (Yayımlanmamış yüksek lisans tezi). Kütahya Dumlupınar Üniversitesi, Eğitim Bilimleri Enstitüsü, Kütahya.

Karagöz, B, Sezer, K. ve Sarman, L. (2019). Necati Güngör'ün çocuk öykülerinin duyarlık eğitimi açısından incelenmesi. F. Temizyürek (Ed.), Prof. Dr. A. Halûk Dursun Anısına Uluslararası Türk Kültü̈rü Sempozyumu Dil-Tarih - Coğrafya, 6-8 Aralık 2019, Ankara, Türkiye, Tam Metin Bildiriler içinde (s. 225-235). Ankara: Asos.

Karagöz, B. (2009). Yapılandırmacı yaklaşıma göre ilköğretim 6 ve 7.sınıf Türkçe ders kitaplarındaki değerlerin incelenmesi (Yayımlanmış Yüksek Lisans Tezi). Muğla Üniversitesi, Sosyal Bilimler Enstitüsü, Muğla.

Karagöz, B. (2017). Türkçe öğretmeni adaylarının çocuk ve gençlik edebiyatı yapıtlarının temel özelliklerini bilme yeterlikleri. Electronic Turkish Studies, 12(14), 211-230.

Karagöz, B. (2018). The historical development of children's literature in Turkey. Universal Journal of Educational Research, 6(5), 848-856.

Karagöz, B. ve Çinpolat, E. (2017). Füsun Çetinel'in romanlarına duyarlık eğitimi bağlamında bir bakış: Bir çözümleme çalışması. IV. Yıldız Sosyal Bilimler Kongresi'inde (21-22 Aralık 2017) sunulan bildiri, İstanbul: Yıldız Teknik Üniversitesi.

Karagül, S. (2019). Çocuk edebiyatının temel işlevleri: Felski'nin yaklaşımı doğrultusunda bir değerlendirme. Dil Eğitimi ve Araştırmaları Dergisi, 5(2), 334-351.

Karakuş Aktan, E. (2019). Duyarlık eğitiminde çocuk edebiyatı yapitlarının yeri. S. Karagül (Ed.), Prof. Dr. Sedat SEVER'e Armağan Türkçe Eğitimi ve Çocuk Edebiyatı Kurultayı, 25-26 Nisan 2019, Tam Metin Kitabı içinde (s. 178-179). Ankara: Ankara Üniversitesi Basımevi.

Karakuş Tayşi, E. (2019). Sevim Ak'ın öykülerinin duyarlık eğitimi açısından incelenmesi. Dil ve Edebiyat Araştırmalarl, (19), 303-324. https://doi.org/10.30767/diledeara.542628

Kavcar, C. (1999). Edebiyat ve eğitim. Ankara: Engin Yayınevi. 
Merriam, S. B. (2013). Nitel araştırma desen ve uygulama için bir rehber (Çev: Selahattin Turan). Ankara: Nobel Yayınc1lik.

Miles, M. B. ve Huberman, A. M. (1994). Qualitative data analysis: An expanded sourcebook. London: SAGE Publications.

Oğuzkan, F. A. (2013). Yerli ve yabancı yazarlardan örneklerle çocuk edebiyatı (10.Baskı). Ankara: Anı Yayınc1lik.

Robson, C. (2001). Real world research. Oxford: Blackwell Publishers.

Sever, S. (2017). Çocuk ve edebiyat. İzmir: Tudem Yayınları.

Şirin, M. R. (2016). Edebiyat ve çocuk edebiyatı, edebiyatın amacı ve işlevi. Türk Dili Dergisi. CX (780), $12-31$.

Tekşan, K. (2016). Çocuk okurların gözünden Fazıl Hüsnü Dağlarca'nın şiirleri. S. Dilidüzgün (Ed.). Kuram ve uygulama bağlamında Türkçe öğretimi içinde (s. 593-608). Ankara: Anı Yayıncılık.

Yıldırım, A. ve Şimşek, H. (2011). Sosyal bilimlerde nitel araştırma yöntemleri (8. Basım). Ankara: Seçkin Yayınları. 